\title{
The Return of Typhoid Mary? Immigrant Workers in Nursing Homes
}

\author{
Shefali Milczarek-Desai, JD, MA and Tara Sklar, JD, MPH \\ Address correspondence to Professor Shefali Milczarek-Desai at shefalimdesai@arizona.edu. Shefali \\ Milczarek-Desai is Assistant Clinical Professor of Law and Director of the Workers' Rights Clinic \\ at the University of Arizona, James E. Rogers College of Law. Tara Sklar is Professor of Health Law \\ and Director of the Health Law \& Policy Program at the University of Arizona, James E. Rogers \\ College of Law.
}

\begin{abstract}
Nursing homes are dependent on immigrant, female labor as nursing aides, yet these workers are provided with minimal employment benefits, which has led to devastating consequences for vulnerable, older residents during COVID-19. Emerging research suggests that aides are contributors to the increase in coronavirus outbreaks due to working in multiple long-term care facilities and refer to these individuals as "superspreaders." Specifically, aides have been tied to unwittingly passing on the virus as they may be asymptomatic or pressured to work by employers while symptomatic with limited access to paid sick leave. The plight of these women harkens back to "Typhoid Mary" - also a poor, immigrant woman who was accused of spreading typhoid fever a century ago. This article applies lessons learned from Mary's shocking and tragic trajectory, then employs critical race theory and feminist jurisprudence to highlight examples of structural and institutional disparities that exist in current paid sick leave laws. Recommendations call for improved oversight in delivery of quality and safety in long-term care by addressing racial, gender, and economic inequalities through paid sick leave laws coupled with strong enforcement.
\end{abstract}

Keywords: COVID-19, long-term care, paid sick leave, immigrant workers

\section{¿El regreso de "Typhoid Mary"? Trabajadores inmigrantes en hogares de ancianos}

\section{RESUMEN}

Los hogares de ancianos dependen de la mano de obra femenina inmigrante como auxiliares de enfermería, sin embargo, estos trabajadores reciben beneficios laborales mínimos, lo que ha tenido consecuencias devastadoras para los residentes mayores vulnera- 
bles durante el COVID-19. La investigación emergente sugiere que los asistentes contribuyen al aumento de los brotes de coronavirus debido al trabajo en múltiples instalaciones de atención a largo plazo y se refieren a estas personas como "superpropagadores". Específicamente, los asistentes han estado vinculados a la transmisión involuntaria del virus, ya que pueden ser asintomáticos o presionados para trabajar por los empleadores mientras tienen síntomas y tienen acceso limitado a la licencia por enfermedad con goce de sueldo. La difícil situación de estas mujeres se remonta a "Typhoid Mary", también una mujer pobre e inmigrante que fue acusada de propagar la fiebre tifoidea hace un siglo. Este artículo aplica las lecciones aprendidas de la impactante y trágica trayectoria de Mary, luego emplea la teoría crítica de la raza y la jurisprudencia feminista para resaltar ejemplos de disparidades estructurales e institucionales que existen en las leyes actuales de licencia por enfermedad remunerada. Las recomendaciones piden una mejor supervisión en la prestación de calidad y seguridad en la atención a largo plazo al abordar las desigualdades raciales, de género y económicas a través de leyes de licencia por enfermedad pagadas junto con una estricta aplicación.

Palabras clave: COVID-19, cuidados a largo plazo, licencia por enfermedad remunerada, trabajadores inmigrantes

\section{伤寒玛丽的回归？疗养院的移民员工}

\section{摘要}

疗养院依靠移民女性劳动力作为护理助手, 然而这些员工却 获得最低的就业利益, 导致2019冠状病毒病期间脆弱的老年 居民遭受破坏性结果。新兴研究暗示, 护理助手对病毒爆发 作贡献, 因为前者在多个长期护理设施中工作, 研究还将这 些个体称为 “超级传播者”。具体而言, 护理助手无意地传 播病毒, 因为他们可能没有症状, 或在雇主压力下工作的同 时出现症状但没有足够的带薪病假。这些女性的困境让人联 想到 “伤寒玛丽”，她也是一名贫穷的妇女，100年前被指 责传播伤寒。本文应用了从伤寒玛丽惊人且悲剧性经历轨迹 中得出的经验, 随后使用批判性种族理论和女性主义法律, 强调当前带薪病假法中存在的结构性差异和制度性差异。本 文提出建议, 呼吁通过带薪病假法和强有力的法律执行, 以 应对种族、性别和经济方面的不平等, 进而在长期护理的质 量和安全交付过程中提高监管。

关键词: 2019冠状病毒病, 长期护理, 带薪病假, 移民员工 


\section{Introduction}

The number of COVID-19 infections and related deaths in nursing homes continue to climb and, as a result, the underlying labor conditions that are contributing to this spread are being exposed. Specifically, low-wage workers, including women of color and immigrants, employed as aides in nursing homes and other long-term care facilities comprise nearly one-third of the workforce (Zallman et al., 2019), and have been linked to tens of thousands of COVID-19 deaths (Barnett \& Grabowski, 2020; Yourish et al., 2020; Chen et al., 2020). ${ }^{1}$ These workers are directly responsible for providing care to some of the most vulnerable Americans due to older age, disabilities, or complex medical needs, yet their essential work is undervalued as shown by low pay and limited benefits. The highly infectious coronavirus has formed a deadly intersection where low-wage, immigrant women employed as aides collide with a medically fragile population. This article proposes law and policy recommendations that aim to prevent further collisions by improving labor conditions that have been shown to decrease rates of infection.

This article is organized into the following four sections. Section I provides a historical background of how previous epidemics have exposed gross inequalities in workers' rights and benefits, which created grave risks to public health and safety for all Americans. The story of Mary Mallon, dubbed "Typhoid Mary," who was a poor, Irish immigrant living during the turn of the last century has many parallels to a modern-day immigrant woman, we'll call her Salma, ${ }^{2}$ who works as a nursing home aide. Section II employs critical race theory and feminist jurisprudence to analyze current structural biases in laws and policies that lead to inequitable outcomes for low-wage, immigrant women. In Section III, a detailed overview of employment benefits, namely paid sick leave, are reviewed in combination with these analytical frameworks, which together formulate the proposed recommendations in Section IV. Notably, many of these recommendations could have been pursued long before the COVID-19 crisis began unfolding. What has been missing, until this moment, is the will to protect low-wage immigrant workers and as a result, safeguard the most vulnerable members of society.

\section{Historical Background of Epidemics and Gross Inequities}

1 In March of 2020, nursing homes had been linked to over 316,000 COVID-19 cases and 57,000 deaths, which at the time represented almost half of all U.S. fatalities from the virus. The Proceedings of the National Academy of Sciences published a study in January 2021, which found that 49 percent of the COVID-19 outbreaks in nursing homes can be traced to cross-facility staff movement. Available at: https://www.pnas.org/content/118/1/e2015455118.abstract

2 "Salma" was a client in the Workers' Rights Clinic at the University of Arizona, James E. Rogers College of Law, which is a student-run clinic that provides legal advice and representation in the areas of employment and labor law to low-wage immigrant workers. 
January of 2020 and is the most recent public health crisis to spotlight gross inequities embedded in American labor and healthcare systems. Throughout U.S. history, epidemics have both exacerbated and highlighted the challenges faced by low-wage immigrant workers. The stark similarities between "Typhoid Mary," a poor, immigrant woman who was labeled the most dangerous woman in America over a century ago (Walzer Leavitt, 1996), is detailed below and confirms how little has changed in strategies of disease containment. Specifically, repeating the pattern of "punitive disease control" (Hoppe, 2017, p. 19), where the focus is on "the need for protection against individuals who threaten the public's health" (Walzer Leavitt, 1996, p. 160), instead of the conditions those workers find themselves forced to endure.

\section{The Story of "Typhoid Mary"}

During the nineteenth and early twentieth centuries, the U.S. experienced several typhoid fever epidemics due to the contagious nature of the typhoid bacterium, Salmonella Typhi. This infectious disease spread disproportionately among the poor, in environments that lacked widespread sanitation and clean water supplies (Walzer Leavitt, 1996). One of the most prominent figures from that era is a woman named Mary Mallon-infamously known as "Typhoid Mary" - who worked as a cook for wealthy New Yorkers (Foss, 2020; Walzer Leavitt, 1996, p. 29). Like many low-wage immigrants working during
COVID-19, Mary had little choice but to labor in a frontline industry to earn a livelihood (Hoppe, 2017) where she was not provided paid sick leave and had limited access to healthcare. ${ }^{3}$

Mary Mallon was an "immigrant woman who made her way" after crossing the ocean by boat from Ireland to the U.S. as a teenager (Walzer Leavitt, 1996, p. xvii). She worked from an early age, and like many young, Irish immigrant women at the time, job opportunities outside the realm of domestic labor were scarce (Walzer Leavitt, 1996). Moreover, historical records and scholars of labor and immigration have described that these women:

[A]ccepted servanthood as a fact of life ... The conditions of [Mary] Mallon's life as a domestic servant at the turn of the century were undoubtedly grim ... A typical day began at 6:00 A.M. and did not end until after-dinner cleaning, well into the evening hours. Usually the women were on their feet the entire day, except when they took their own meals, which were often leftovers from the family table. (Walzer Leavitt, 1996, p.164)

Nonetheless, Mary managed to overcome her humble beginnings, and cultivate a reputation as an admirable cook where she rose through the ranks until landing a high-status position working for New York City's wealthy elite (Walzer Leavitt, 1996).

3 As discussed infra at 16, in Mary Mallon's time, most workplace laws such as paid sick leave did not exist for any workers. 
In the early 1900s, New York City and other large metropolitan areas were making a great effort to prevent the spread of typhoid fever as it was a deadly disease with fatality rates of about ten percent (Walzer Leavitt, 1996; Hoppe, 2017 , p. 21). However, like COVID-19, not everyone who contracted Salmonella Typhi became ill and there were individuals described as "healthy carriers" (Walzer Leavitt, 1996). Health departments were engaged in using contact tracing to identify asymptomatic individuals since they had the potential to unwittingly spread typhoid to large numbers of people, especially if they worked in frontline jobs such as food preparation (Walzer Leavitt, 1996).

In 1907, Mary became the focal point of one such investigation. Several members of a wealthy family she had cooked for became sick with typhoid fever and, partially because it was unusual for affluent individuals to come into contact with this disease, they hired a private investigator to determine the source of their illness (Walzer Leavitt, 1996). Mary, not believing she was a carrier because she felt "healthy," refused to provide the investigator with samples of her feces, urine and blood for testing. Historian Judith Walzer Leavitt (1996) notes the fear and anger Mary likely experienced at the onset of this investigation (Wu, 2020). The public health investigator accused Mary of being "dirty" when her entire livelihood depended on her reputation as a clean, excellent cook.

Mary's refusal to cooperate led the New York City health department, with the aid of the police, to remove Mary Mallon forcibly from the home she was working at, hospitalize her to obtain the requisite samples, and then imprison her-without any due process or hearing-on New York's North Brother Island for three years (Walzer Leavitt, 1996, pp. 19-20; Foss, 2020). Mary tested positive as having had Salmonella Typhi, and it is believed she encountered the bacterium sometime during or before 1900. After spending three years in forced quarantine, a new health commissioner permitted Mary's release in 1910 on the strict condition that she not seek employment as a cook (Walzer Leavitt, 1996; Foss, 2020). She agreed and set about working as a laundress (Walzer Leavitt, 1996; Hoppe, 2017). This, however, did not pay as much as working as a cook, and lacked other benefits.

Over time, Mary grew "frustrated with the lower wages of laundry work" (Hoppe, 2017, p. 21) and took on "an alias to conceal her widely reported identity [and] return to cooking," this time at the Sloane Maternity hospital (Hoppe, 2017, p.21). Soon thereafter, the hospital experienced an outbreak of typhoid fever that officials tracked to Mary, who was working under a pseudonym. Between 1900 and 1915, Mary "spread typhoid fever to at least 53 people, causing three deaths" (Foss, 2020; Walzer Leavitt, 1996, p. xvii). New York City health authorities arrested Mary and sent her back to North Brother Island, once again without any due process. She lived in isolation and practically imprisoned for the next 23 years until she died in 1938, alone and in forced quarantine (Walzer Leavitt, 1996; Hoppe, 2017; Foss 2020). 
Around the same time Mary's saga was unfolding, there were "approximately 400 other healthy carriers" of typhoid who had been identified in New York. Notably, none of them were forcibly removed from their homes and institutionally quarantined (Foss, 2020; Walzer Leavitt, 1996, p. 54). Walzer Leavitt (1996) writes in her biography of Mary Mallon that although health officials tracked a few of these cases, they were all men who neither were arrested nor imprisoned. Walzer Leavitt (1996) proposes prevailing gender stereotypes at the time as the reason, noting that they were recognized as heads of households and therefore were allowed to continue earning wages for their families. By contrast, Mary was an unmarried woman with no dependents. Katherine Foss (2020), also an historian, adds that Mary's status as a lowwage immigrant worker contributed to this inequal treatment. Public health authorities mandated that other healthy carriers stop working in the food services industry and required these individuals to show up for period check-ins with officials. Authorities, however, ultimately were unsuccessful in keeping tabs on most asymptomatic carriers, many of whom later were found to have returned to preparing food for the public. In sum, healthy carriers who were predominately male and less likely to be from poor, immigrant backgrounds, did not receive the punishment that Mary endured for similar actions (Wal- zer Leavitt, 1996).

The story of "Typhoid Mary" is instructive because it shows how past failures to provide workers' rights and benefits further endangers the public's health and safety during an infectious disease outbreak. In addition, efforts to restrict, remove or isolate so-called superspreaders (Vandinther, 2020) ${ }^{4}$ from the public, risks discrimination and places greater economic burdens on those from less privileged backgrounds. It is perilous both to individual liberty rights and to public health outcomes to ignore the labor conditions that encourage low-wage, immigrant workers to knowingly or unknowingly spread contagious diseases (Walzer Leavitt, 1996; Vandinther, 2020).

In applying these lessons from over a century ago to today, tens of thousands of low-wage immigrant workers continue to show up to work even after being exposed to or falling ill from COVID-19 (Jabour, 2020; Jordan \& Dickerson, 2020; Barbaro \& Dickerson, 2020; Sonmez et al. 2020). Nowhere has this stark reality become more evident than with low-wage immigrant workers who are commonly employed as aides within nursing homes (Lee, 2020; Yearby \& Mohapatra, 2020b; Booker, 2020). ${ }^{5}$ While nursing home residents are only one percent of the population, they represent over 41 percent of COVIDrelated deaths nationwide (Conlen et al., 2020). Nursing homes and long-term

\footnotetext{
4 "Historians who have studied Mary Mallon's life have argued that she was not, in fact, a "superspreader" in that she infected at most 50 people when many other asymptomatic typhoid carriers infected far more people than that."

5 One sensationally publicized example of this is the case of Josefina Brito-Fernandez, who worked
} 
care settings house the most vulnerable to this lethal disease, yet rather than take efforts to improve quality and safety conditions by addressing paid sick leave for nursing home aides, as one example to curtail the spread, thousands of long-term care residents continue to die before their time. The following is the story of a worker from today's pandemic illustrating the deadly intersection of low-wage, immigrant workers and long-term care.

\section{Salma's Story: An Immigrant Nursing Homes Aide}

Salma works as an aide in several nursing homes. She, like many other immigrant women, works in multiple facilities in order to earn enough income to support herself and her family. She spends up to twelve hours a day bathing, dressing, feeding, and medicating residents as well as cooking and cleaning in the homes. ${ }^{6}$ When COVID-19 hit the United States, Salma's employer did not provide personal protective equipment (PPE), nor did it increase Salma's pay or provide her with hazard pay. ${ }^{7}$

Salma's employer also refused to provide her with paid sick time off from work, even though the state in which Salma resides has a paid sick time law that entitles her to that leave. On the occasions Salma requested paid sick time, her employer threatened to report her to Immigration Customs and Enforcement. When Salma stated she had legal status, her employer changed tactics and threatened to report her to the Internal Revenue Service because no payroll taxes had been deducted from Salma's pay since she was paid "off the books." ${ }^{8}$ Moreover, underlying both threats was an implicit message from Salma's employer: assert your rights and you will find yourself with greater problems than lack of paid sick leave, namely the loss of your job. Salma's employer's actions are common among employers of low-wage immigrant workers in the United States.

Salma, like many low-wage immigrant nursing home aides, cannot risk being terminated from her employment especially during COVID-19. The nation's burgeoning unemployment rates coupled with decreasing unemployment benefits continue to climb as the pandemic remains uncontrolled (Walzer Leavitt, 1996; ${ }^{9}$ Cohen \& Hsu,

as a home health aide in New Jersey. In April of 2020, Brito-Fernandez went back to work after being told to self-quarantine after taking a COVID-19 test. Five members of the home in which she worked ended up testing positive for COVID-19, and an 80-year-old patient being cared for by Brito-Fernandez died from the coronavirus infection. New Jersey prosecutors charged Brito-Fernandez with endangering the welfare of others in a complaint and summons filed on May 14, 2020.

6 Mary Mallon too likely would have worked "very long work days with little time off." (Walzer Leavitt, 1996, p. 166).

7 Similarly, domestic servants like Mary Mallon often "labored under 'defective sanitation ... poor bathing facilities" and other unclean conditions. (Walzer Leavitt, 1996, p. 166).

8 Importantly, it is the employer's duty to ensure payment of all state and federal payroll taxes and not the employee's responsibility.

9 Mary Mallon faced similar "struggle and vulnerability" because "[1]ike others of her status and occupation, she remained expendable throughout her working careers. She could have been replaced 
2020). As a result, if she or someone in her household becomes ill with the novel coronavirus, then Salma will have to choose between loss of crucial income or potentially contributing to the spread of the virus. Indeed, emerging evidence suggests that aides are tied to unwittingly increasing COVID-19 outbreaks, either because they are asymptomatic or their employer has pressured them to work while sick (Chen et al., 2020).

Salma's story hearkens back to Mary Mallon's saga on multiple levels. During the typhoid epidemic, cooks were among the most dangerous superspreaders because, given early twentieth century hygiene, typhoid bacteria was easily spread from one's fecal matter to hands to food (Walzer Leavitt, 1996). ${ }^{10}$ During COVID-19, some of the most dangerous superspreaders are nursing home aides ${ }^{11}$ especially when they work in more than one location (Chen et al., 2020). ${ }^{12}$ This is largely due to the type of work required to care for an older adult and how COVID-19 is transmitted. Personal care needs of an older population cannot be realistically met without some level of physical contact-64 percent need help with bathing, 57 percent with walking, 48 percent with dressing, 40 percent with toileting, and 42 percent have dementia-making handwashing and other safety measures difficult to implement (Coe \& Harold Van Houtven, 2020).

Indeed, as more evidence becomes available, aides like Salma, and similar low-wage immigrant workers are increasingly identified as major contributors to the spread of the coronavirus (Chen et al., 2020; Zimmer, 2020). However, unlike Mary, federal and state paid sick leave laws now exist that are designed to protect workers and the general public from devastating disease outbreaks. As the next section explains, however, these laws are not providing the protection workers like Salma need in order to stop the spread of the virus.

\section{Structural Labor Inequities Through the Lens of Critical Race Theory and Feminist Jurisprudence}

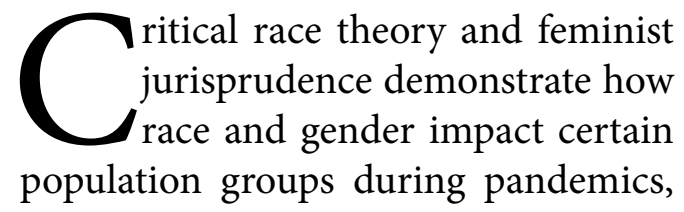

without any notice. She experienced periods of unemployment." (Walzer Leavitt, 1996, p. 168).

10 Although early twentieth century hygiene played a large role in the spread of Typhoid Fever, it should be noted that United States immigration laws, policies and rhetoric have long cast lowwage immigrant workers as being dirty or carrying disease especially during infectious outbreaks (Aleinikoff et al., 2016). This has also been the case during the COVID-19 pandemic. (Dickerson and Shear, 2020).

11 "With an elderly resident population, many with underlying chronic medical conditions, congregate living quarters, and routine contact with staff members and outside visitors, nursing homes are particularly vulnerable to outbreaks of respiratory pathogens" (Chen et al., 2020).

12 In this recent large empirical study based on geo-location data collected from smartphones, researchers found that nursing homes with staff employed at multiple nursing home facilities experienced greater COVID-19 outbreaks. 
in part, by showing that these groups lack access to benefits from laws and policies, such as paid sick leave (Bridges, 2019). ${ }^{13}$ Taken together, these analytical frameworks focus "on the law's role in mitigating, perpetuating, or exacerbating" the challenges faced by women of color (Bridges, 2019). ${ }^{14}$ In the context of COVID-19, these critical lenses reveal and examine inequities within the labor, employment and public health spheres that have contributed to high numbers of COVID-19 infections and deaths in America's nursing homes. Specifically, they consider whether people of color, immigrants, and/or women are disproportionately affected by the pandemic and if so, why and how. In asking these questions, critical race theory and feminist jurisprudence interrogate the efficacy of existing paid sick leave laws and policies within the COVID-19 context and propose recommendations to better protect vulnerable groups.

Public health scholars have long known that disease outbreaks are far more devastating to racial and ethnic minorities in the United States than for their white counterparts. Examples from both the 1918 influenza and the 2009 H1N1 pandemics show similar disparate outcomes occurring during COVID-19 (Yearby \& Mohapatra, 2020a). The COVID-19 pandemic has had a grossly disproportionate impact on Black, Latinx, ${ }^{15}$ and immigrant workers both in terms of susceptibility of contracting the virus and severity of the illness up to and including death (Oppel et al., 2020; ${ }^{16}$ Barbaro et al., 2020; Beyer, 2020; Gebeloff et al., 2020; Calderon et al., 2020). Data collected by the Centers for Disease Control from 640,000 infections across nearly 1,000 U.S. counties shows that Black and Latinx individuals are three times as likely to become infected from the novel coronavirus and twice as likely to die from it (Oppel et al., 2020). ${ }^{17}$ A report by Congress' Joint Economic Committee further found that the working poor and people of color have been "hit hardest" by the virus "far out of proportion to their numbers" (Beyer, 2020).

While pre-existing conditions might explain, to some degree, why

13 Critical Race Theory ("CRT") "emerged in the 1970s and 1980s" and is based on the notion that the legal system itself "plays a crucial role in maintaining the significance of race" (Bridges, 2019, p. 87). Despite its name, CRT does not stop its analysis of structural inequities at race, but rather is concerned with the intersectionality of oppressions that exist in law and society including gender, class, and sexual orientation.

14 Referring to the intersection of critical race theory and feminist jurisprudence as "critical race feminism."

15 Following Khiara Bridges' lead, this paper "uses the term Latinx, instead of Latino/a ... as a gender inclusive, non-binary reference to people of Latin American descent" (Bridges, 2019, p. 1).

16 The data set forth in this article was the result of a Freedom of Information Act Requested directed to the Centers for Disease Control to obtain the first set of comprehensive data, representing over half of the country, on COVID-19 infections and deaths by race and ethnicity.

17 Pointing out that these numbers are actually skewed low because the white people dying from COVID-19 mostly reside in nursing homes; in other words, the rates at which Black and Latino individuals contact and die from the virus are much higher when compared to the general population of white individuals as opposed to all whites who have contracted and died from the virus. 
Black, Latinx, and immigrant communities have higher death rates during pandemics (Villarosa, 2018), comorbidities do not account for higher infection rates (Oppel et al., 2020; Barbaro et al., 2020). Rather, critical race theorists have posited that " $[\mathrm{r}]$ acial and ethnic minorities are disproportionately impacted during pandemics ... not due to any biological difference between races, but . . . as a result of social factors" (Yearby \& Mohapatra, 2020a or b?). Congress' Joint Economic Committee reached the same conclusion in stating that " $[\mathrm{w}]$ hile it has long been understood that wealth, race and health are closely tied, COVID-19 has focused attention on the high human cost of structural inequalities in American society" (Beyer, 2020).

One of the most determinative social factors contributing to racial and ethnic minorities' increased risk of exposure to disease during pandemics is the type of work performed by these individuals (Yearby \& Mohapatra, 2020a; Oppel et al., 2020; Barbarao et al. 2020). Black, Latinx and immigrant workers in the United State are more likely to be employed in low-wage jobs within frontline, essential industries "that do not provide the option to work at home and [these workers] cannot afford to miss work even when they are sick" (Yearby \& Mohapatra, 2020a; Calderone et al., 2020). ${ }^{18}$ During the H1N1 outbreak, a national survey reported "racial and ethnic minorities were unable to practice social distancing or stay at home ... because they could not work at home and lacked paid sick leave" (Yearby \& Mohapatra, 2020a; Kumar et al., 2013). Similarly, emerging country-wide data and regional studies on the impact of COVID-19 on low-wage workers demonstrate that the same factors-inability to telework coupled with lack of access to paid sick leave-are significantly contributing to this pandemic's disparate impact on racial and ethnic minorities (Hammonds \& Kerrissey, 2020; Oppel et al., 2020; ${ }^{19}$ Calderone et al., 2020).

The largest data collected on essential, low-wage workers and COVID-19 to-date is based on a Spring 2020 survey conducted in Massachusetts with 1600 participants, $72 \%$ of whom were women (Hammonds \& Kerrissey, 2020). The responses revealed that over half of the workers surveyed did not believe their employers were taking the proper precautions to protect them from COVID-19 (Hammonds \& Kerrissey, 2020). These workers, however, "lacked the option to quit" if they felt unsafe because "[w]ith little savings, low-wage workers depend on their paycheck-walking away can feel like it is not an option" (Hammonds \& Kerrissey, 2020). The survey also found that despite Massachusetts' paid sick time law and the new federal emergency paid sick time law specifically creat-

18 Discussing findings by public health experts in New York finding that immigrants working in lowwage jobs in their state do not have the option to work from home and as a result, have much greater risk of exposure to COVID-19 when they are on the job.

19 One Latinx immigrant mother is quoted in the article saying, "We have to go out to work ... [w]e have to pay our rent. We have to pay our utilities. We just have to keep working." 
ed for workers during the current pandemic, a large percentage of surveyed workers lacked access to paid sick time off from work (Hammonds \& Kerrissey, 2020). When these workers are employed in frontline essential industries, such as nursing homes, showing up to work sick has "critical public health implications" (Maloney \& Schumer, 2010 p. $8 ;{ }^{20}$ Quandt et al., 2020; ${ }^{21}$ Sonmez et al., 2020).

Women of color especially are impacted by the COVID-19 pandemic because, as census data show, "one in three jobs held by women has been designated as essential during this pandemic, and nonwhite women are more likely to be doing essential jobs than anyone else." This is borne out in the home health care industry, where two-third of the workers are women of color. Thus, nursing home aides like Salma are more likely than other workers to be exposed to, contract, and spread COVID-19 (Yearby \& Mohapatra, 2020a; Quandt et al., 2020; Sonmez et al., 2020; Yearby \& Mohapatra, 2020b). ${ }^{22}$

When the COVID-19 crisis in nursing homes is viewed through the lenses of critical race theory and feminist jurisprudence, it becomes clear that race and gender are implicated in terms of who is most likely to get sick from and spread the virus. Next, this paper utilizes these analytical frameworks to explain why existing laws and policies do not protect the very groups most in need of them.

\section{Failures of Current Paid Sick Leave Laws: Underreported, Underenforced, and Underfunded}

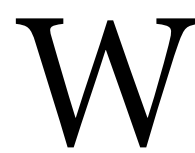
hen Mary Mallon and other immigrant women like her eked out a living cooking, cleaning and caregiving for others, there were no laws requiring that workers earn a minimum amount per hour, be paid more if they worked over a certain number of hours a week, or be paid for time they had to take off from work due to illness. This all changed in 1938, when one of the most important pieces of New Deal legislation, the Fair Labor Standards Act ("FLSA"), was enacted. The FLSA requires employers to provide workers with a federal, hourly, minimum wage, and overtime pay (i.e., time and a half) for all hours worked over forty in a seven-day work period. ${ }^{23}$

20 Nationwide data shows that this is true for immigrant workers in the agricultural and hospitality industries as well.

21 Finding that Latinx farmworkers are "deemed essential" and therefore cannot shelter at home to reduce their risks of contracting COVID-19.

22 Stating that "Ninety percent of home health care workers are women, and two-third of them are women of color" many of whom are living below federal poverty guidelines and lack health insurance.

23 The FLSA initially excluded protections for domestic workers, who at the time overwhelmingly were poor, black women and other women of color. These exclusions can be traced to the aftermath of the Civil War and the Antebellum South. The National Labor Relations Act, continues to exclude domestic workers from its protections. Although nursing aides working in long-term care facilities are not considered domestic workers, it is important to note that the law's systemic failure to 
The FLSA's savings clause explicitly states that it is a floor so states may legislate a higher minimum wage or overtime rate, and many states and some localities have done so. ${ }^{24}$ Slower to take hold has been the right of a worker to collect pay even when she cannot work due to illness or the need to care for her own or a family member's health. It is this right, which most of the world's wealthiest countries adopted long ago (DeSilver, 2020; ${ }^{25}$ Garrity, 2017), that is a focal point because low-wage immigrant workers' inability to access paid sick leave is a critical factor in the spread of COVID-19 in nursing homes (Yearby \& Mohapatra, 2020a; Barnett \& Grabowski, 2020).

In the United States, it has been state and local governments, not the federal government ${ }^{26}$ (Weston Williamson, 2019; Garrity, 2017), that have led the charge in enacting paid sick time legis- lation. San Francisco was the first jurisdiction to pass a paid sick time law in the United States in 2006 (San Francisco Paid Sick Leave Ordinance, Administrative Code Chapter 12W, 2019) ${ }^{27}$ with Washington D.C., Seattle, and Milwaukee passing similar laws soon thereafter (Wash, D.C. Code $\$ 32-131.02$ (2014); Seattle Wash., Code $\$ \$ 14.16 .010-.130$ (2019); Milwaukee, Wis., Ordinances $\$$ 112 (2008); ; Weston Williamson, 2019; Garrity, 2017). In 2012, Connecticut became the first state to pass a paid sick time law, followed by a succession of others (Garrity, 2017). ${ }^{29}$ Currently, eleven states and nineteen local jurisdictions, including cities and counties, have enacted some form of paid sick leave for their workers bringing the total number of nationwide paid sick time laws to thirty (A Better Balance, 2020a; see also Weston Williamson, 2019). ${ }^{30}$

These laws require that workers

protect immigrant women who work in long-term care facilities can be traced, in part, to historical legal exclusions of women of color in similar, caregiving industries where they make up a large portion of the workforce (Lin, 2013).

24 ARIZ. REV. STAT. ANN. $\$ 23-363$ et seq. (2020) (establishing Arizona’s state minimum wage at a rate higher than the federal minimum wage); FLAGSTAFF, ARIZ., CODE $\$ 15-01$ (2016) (establishing a minimum wage for the City of Flagstaff that exceeds the state minimum wage beginning in 2020).

25 "The U.S. and South Korea are the only two countries in the Organization for Economic Cooperation and Development where paid sick leave is not guaranteed ... [a]ll European Union member countries have some form of paid sick leave."

26 Prior to the COVID-19 pandemic, the only federal leave law that existed was the Family and Medical Leave Act ("FMLA"), which provides up to twelve weeks of unpaid leave and job restoration protection to certain qualifying workers who need to take time off because they are seriously ill, or are caring for a seriously ill family member or a new child. 29 U.S.C. $\$ \$ 2601$ et seq. This law, does not cover a workers' short-term illness such as those caused by most viruses, including coronavirus, and applies only to employers who have 50 or more workers within a 75 -mile radius and workers who have been at their place of work for one year.

27 S.F., CAL., ADMIN., CODE $\$ \$ 12$ W .1-.16 (2019), https://sfgov.org/olse/PAID-SICK-LEAVE-ORDINANCE-PSLO.

28 Milwaukee's law, which was passed by voter referendum, was later repealed by the state legislature.

29 Noting that Arizona's and Washington's laws were passed by voter initiative.

30 Noting that the current number of paid sick time laws on the books do not reflect laws that have been repealed or passed by municipalities but preempted by hostile state legislatures. 
be permitted to take time off and be paid for that time when they or a family member is "sick, injured, or seeking medical treatment (including for mental health and preventative care)" (Weston Williamson, 2019; A Better Balance, 2020a). Some paid sick time laws also permit workers to be paid for time away from work caused by domestic violence or a public health emergency like COVID-19 (see e.g., Arizona Revised Statutes Title 23. Labor $\$ 23$ 371). Importantly, all state, county and municipal paid sick time laws are based on an accrual model, which means that workers must earn their paid sick time hours (Weston Williamson, 2019). In Arizona, for example, workers earn one hour of paid sick time for every thirty hours worked and can use between twenty-four (three eight-hour days) and forty hours (five eight-hour days) of paid sick leave in any given year depending on the number of employees at their place of work (Arizona Revised Statutes Title 23. Labor $\$ 23-372-73)$. This is typical of paid sick time laws across the country (Weston Williamson, 2019).

Since 2005, Congressional Democrats repeatedly have tried but failed to pass national, universal paid sick leave legislation. The purported lawthe Healthy Families Act ("HFA") would have provided much the same rights that now exist under the thirty jurisdictions with earned paid sick time laws (Garrity, 2017). ${ }^{31}$ When the H1N1 pandemic struck in 2009, impacting millions of American workers, members of Congress tried to pass the "Pandemic Protection for Workers, Families, and Businesses Act," which would have provided seven paid sick days to a worker who had contracted the virus or who had to care for a dependent who had fallen ill from H1N1 (Garrity, 2017). This legislation also failed to become law. Soon thereafter, Congress' Joint Economic Committee issued a report estimating that if the HFA had been in place in 2010, it would have provided at least 30.3 million additional workers in America with paid sick leave (Maloney \& Schumer, 2010). Thus, long before COVID-19 hit American shores, Congress's failure to enact a federal paid sick time law has sustained and perpetuated racial and gendered inequities that force low-wage immigrant women like Salma to report to work sick thereby also endangering America's older populations (Maloney \& Schumer, 2010, p. 7). ${ }^{32}$

\section{COVID-19 and Universal Paid} Sick Leave

Stalwart political resistance to passing a national, universal paid sick leave law finally gave way amidst fears of the highly contagious and deadly nature of

31 The federal law would have been more generous than most local laws in that it would have permitted workers to earn up to seven days of paid sick leave time in a year so long as their workplaces contained fifteen or more employees.

32 Finding that in "nearly half ( 49 percent) of all Latino employees in businesses with more than 15 employees have no access to paid sick leave." 
COVID-19 (Bridges, 2019). ${ }^{33}$ In March of 2020, Congress passed the historic Families First Coronavirus Relief Act ("FFCRA") - the first federal law ever to provide workers with a right to paid sick time (116 P.L. 127, 2020 Enacted H.R. 6201; Boyens, 2020). The law, however, is temporary in nature and limited in scope. It is effective only from April 1 to December 31, 2020, and applies only to leave taken for COVID-19 purposes. ${ }^{34}$ Specifically, the FFCRA provides up to 80 hours (two weeks at eight hours a day) of paid sick time to workers whose employers are public agencies or private employers with less than 500 employees if a worker is 1) unable to work or telework due to COVID-19 symptoms and is seeking a diagnosis, 2) ordered to quarantine for a COVID-19 reason by a governmental entity or physician, 3) caring for someone who has been subject to such an order, or 4) caring for their children due to school or daycare closures related to COVID-19.

The exemption for companies with 500 or more employees has negative implications for low-wage workers in long-term care and the residents they serve as the majority of operators in this industry are large, for-profit entities who are exempt from FFCRA. ${ }^{35}$ Additionally, long-term care, especially in home health care arrangements frequently employ aides as independent contractors making it so they are not entitled to paid sick leave under FFCRA. This type of unstable employment classification reflects a larger issue present-what is known as the 'gig economy', which disproportionately impacts low-wage workers, including women of color and immigrants. The systematic misclassifying of regular employees as independent contractors denies them protection from workplace laws. Despite the FFCRA's broad exemptions for certain workers it is the closest thing to a universal paid sick time policy in the United States.

Of paramount importance is that all paid sick time laws-state, local, as well as the FFCRA-contain anti-retaliation provisions (Arizona Revised Statute $\$ 23-374$ (2020); 116 P.L. $127 \$ \$ 5104$ 05, 2020 Enacted H.R. 6201). In other words, employers may not take adverse employment actions against workers who request, assert their right to, and/ or take paid sick leave. Adverse employment action can take many forms, including reduction in hours, reduction in pay, disciplinary action, the creation of a hostile work environment, a change of job assignment or duties, and, of course, termination (116 P.L. $127 \$ 5105,2020$ Enacted H.R. 6201; FLSA $\$ 215(a)(3))$. Anti-retaliation provisions in some state and local paid sick time laws are quite robust, stating that employers will be

33 Critical race and feminist jurisprudence would also prompt us to ponder whether the reluctance to pass universal paid sick leave is based, in part, on an effort to sustain hegemonic labor systems that maintain social hierarchies that disadvantage low-wage workers, women, and/or people of color.

34 Importantly, the law guarantees employers a dollar-for-dollar refundable tax credit through the Treasury Department.

35 See Private Equity Ownership is Killing People at Nursing Homes, 2021, available at: https://www. vox.com/policy-and-politics/22295461/nursing-home-deaths-private-equity-firms 
presumed to have retaliated if a worker experiences adverse employment action within a certain time period after requesting and/or taking paid sick time leave (Weston Williamson, 2019; Arizona Revised Statutes Title 23. Labor $\$ 23$ 364(B)). ${ }^{36}$ Although the FFCRA does not contain this type of heightened anti-retaliation protection, it clearly states that an employer "may not discharge, discipline, or otherwise discriminate against any employee who takes paid sick leave under the FFCRA and files a complaint or institutes a proceeding under or related to the FFCRA" (116 P.L. $127 \$ 5105,2020$ Enacted H.R. 6201; FLSA $₫ 215(\mathrm{a})(3))$. These anti-retaliation provisions, as well as the penalties (FLSA $₫ \$ 216-217$ ) that attach to employer violations of paid sick time laws, including retaliation, are meant to signal to employers that they will incur greater cost by violating the law than they will by simply abiding by it.

Putting aside for the moment the temporary and limited nature of FFCRA leave, and the fact that over 33.5 million workers in America continue to lack paid sick time for illnesses other than COVID-19 (A Better Balance, 2020a) ${ }^{37}$ existing paid sick leave laws, at least on their face, appear to provide a decent measure of protection for workers. The problem, however, occurs when it comes to accessing and enforcing the rights promised by these laws. It is at this confluence that the ideal of paid sick leave collides with the realities of low-wage immigrant workers lives. Relatedly, an effective paid sick leave law needs to ensure that workers' regularly scheduled paychecks are not reduced if they take sick leave. As many low-wage workers depend on every paycheck to meet basic needs, it would effectively function as a deterrent to request sick leave if their regular pay was reduced since they may not be able to wait for the funds to be added to a later check.

\section{Failures of Paid Sick Leave Laws for Low-Wage, Immigrant Workers}

Even when low-wage immigrant workers have the legal right to accrue and/ or use paid sick leave they either cannot or do not use it to stay home when they have been exposed to COVID-19, as in the case of Josefina Brito-Fernandez (Conlen et al., 2020; Hammonds \& Kerrissey, 2020), ${ }^{38}$ or when they have fallen ill due to some other health reason. This has been dubbed the problem of "presenteeism," and it is a grave threat during a pandemic (Garrity, 2017). The phenomenon of employees showing up to work sick, especially when those workers, like Mary Mallon, work in the food and other frontline industries, is a leading cause of disease outbreaks such as the norovirus outbreak that took place aboard a cruise ship in 2012 (Garrity, 2017), contributed to the spread of the H1N1 virus in 2009 (Gar-

36 Creating a presumption of retaliation if adverse action is taken within ninety days of an employee asserting her right to paid sick time.

37 This count only includes private sector workers.

38 Finding that despite Massachusetts's robust paid sick leave law, large numbers of low-wage workers did not access it. 
rity, 2017; Maloney \& Schumer, 2010, pp 2-3), and generally has been "linked to the spread of harmful contagions to co-workers and customers" (A Better Balance, 2020b). ${ }^{39}$ Not surprisingly, presenteeism is strongly correlated with workers' lack of access to paid sick leave rights (Kumar et al., 2013, p. 1408). To reduce presenteeism, scholars, researchers, and policymakers have advocated for the passage of a universal paid sick leave law or expanding paid sick time laws into states and localities that do not have them. But Salma's story shows that this will not be enough, and critical race and feminist jurisprudence helps explain why.

Low-wage workers, and especially Black, Latinx and female workers within this category, are far less likely than their counterparts to have access to paid sick time. Although this is due in part to the lack of a universal paid sick leave law or the numerous jurisdictions that have not passed local sick time laws, it does not explain why workers like Salma are less likely to ask for and use paid sick leave even when they have the legal right to do so. The reason Salma articulated for her hesitation to ask for paid sick time she had earned is the same for most workers in her position: fear of employer retaliation (Dunne, 2000). ${ }^{40}$

The first fear, shared by low-wage workers from diverse backgrounds, is that of economic retaliation, including cut wages, reduced hours, and termination (Dunne, 2000). Then there is the additional fear faced by immigrant workers that their employers will report them to immigration authorities, which may affect their immediate or extended family members even if they themselves possess documentation and work authorization (Dunne, 2000). Even though all paid sick time laws contain anti-retaliation provisions, enforcement of these provisions is another matter.

Workers who request and are denied paid sick time, or who are retaliated against for seeking or taking paid leave, have two options: they may file a complaint with the appropriate federal or state regulatory agency or sue their employer to enforce their rights. The vast majority of low-wage workers fall into the "access-to-justice" gap, in that they lack the financial wherewithal to hire and pay private attorneys to represent them in a lawsuit, but they also cannot access free legal services because they make just enough to disqualify them from free legal services. More commonly, however, low-wage immigrant workers are excluded from free legal services because federally funded legal aid offices are prohibited from assisting immigrants without documentation $^{41}$ (Heeran, 2011). This means that making a complaint with officials

39 Citing a study conducted in 2009 in support of passing the Healthy Families Act.

40 Citing the federal court for the Northern District of California for the proposition that "[i]t needs no argument to show that fear of economic retaliation might often operate to induce aggrieved employees quietly to accept substandard conditions."

41 There are few exceptions to this broad exclusion involving immigrants seeking visas based on having been victims of trafficking, gender-based violence (such as domestic violence), and who have 
tasked with enforcing sick time laws is the most readily available remedy. If the violation or retaliation occurred under the FFCRA's emergency paid sick time law, the pertinent agency is the U.S. Department of Labor (“DOL") (116 P.L. 127, 2020 Enacted H.R. 6201).

The COVID-19 pandemic, however, has made it painfully apparent that DOL lacks the resources to respond to the deluge of complaints being filed by distraught workers (Labor Department Report, "National Employment Law Project," 2020). Even before the novel coronavirus, DOL was woefully understaffed (Foo, 1994, p.2204). ${ }^{42}$ The same is true for many state and local agencies (Romm, 2020). As a result, most paid sick leave laws in the United States are substantially underenforced, making them practically worthless to workers like Salma because "[a] legal right that cannot be enforced is not really a right at all" (Dunne, 2000, pp. 636-37).

The mere existence of laws like the FFCRA that promise up to 80 hours of emergency paid sick time during the COVID-19 crisis, or state and local laws that allow workers to earn and use paid sick time for a broad range of health-related reasons, is not enough. Moreover, these laws and their regulatory and enforcement mechanisms, however well intended, do not consider the lived reality of large swaths of the low-wage workforce including immigrant women like Salma. To ensure that these essential, frontline workers can access existing and future rights to paid sick leave, additional measures must be implemented.

\section{Recommendations: A Preventable Deadly Intersection}

$\mathrm{P}$ aid sick time laws, alone, do not prevent low-wage immigrant women from becoming superspreaders among vulnerable populations. What policymakers have failed to consider is what will be needed for these laws to become more viable for workers like Salma. Two interrelated interventions, both informed by critical race theory and feminist jurisprudence, provide a starting point ${ }^{43}$ (Boyens, 2020). ${ }^{44}$

First, paid sick time laws must be enforced consistently and at much higher volume than is currently being done.

assisted in criminal investigations.

42 "Under President Carter, the DOL had 1600 wage and hour inspectors to police ninety million workers. Under President Reagan, the number was slashed to 700, and has increased only to 800 during President Clinton's tenure."

43 A third intervention beyond the scope of this paper is state payment of paid sick time to workers rather than requiring employers, who understandably worry about being able to pay sick workers who are not at work while also paying for replacement labor. The FFCRA begins to do this by reimbursing employers for paid sick time costs through dollar-for-dollar tax reimbursements. Even this, however, is not ideal because many employers will be unable to even front costs especially during the deep economic recession precipitated by the COVID-19 pandemic. A recent study shows that leave "claims surged to unprecedented levels" in at least two states - California and Rhode Island - that provide direct payments to workers who take time off for illness or caregiving "beginning in early March."

44 Stating that "this data suggests that these states began helping workers even while federal legislation to provide emergency paid sick and family leave was still under debate" in Congress. 
Part of the problem is lack of resources to fund state and federal labor agencies at a level that would enable them to hire adequate staff to investigate and process worker complaints. Currently, all but eight states and Washington D.C. enforce paid sick time laws through a centralized labor agency (Gerstein, 2020). This approach to enforcement not only drastically limits the number of claims that can be processed at a given time, but it also alienates low-wage workers, especially people of color and immigrants, who are distrustful of officials who operate at a remove from their communities (Gordon, 2005; Walzer Leavitt, 1996). ${ }^{45}$ Alternatively, if low-wage immigrant workers could see, speak with, and/or walk into the offices of local officials to file claims, then they would be more likely to do so. Decentralizing and spreading the burden of paid sick time law enforcement to city, county, and state attorney offices would simultaneously break down barriers low-wage immigrant workers face in filing paid sick time complaints and increase the number of complaints being acted upon. This recommendation could lead to more impact-style litigation (which labor agencies are ill-equipped to handle and rarely engage in) that reverberates beyond a single case (Gerstein, 2020). ${ }^{46}$
Second, localizing paid sick time enforcement creates greater opportunities for outreach and education. Although studies are underway, ${ }^{47}$ it is not yet well understood whether low-wage immigrant workers and their employers, many of whom run small businesses and/or hail from immigrant communities themselves, fully understand the right to paid sick leave much less how to access this right. Anecdotal evidence from workers' rights clinics nationwide suggests that the right to paid sick leave is not well understood and many workers with these demographic backgrounds do not know these laws exists. Tasking and funding local city and county attorney offices with conducting "know-your-rights" and "know-your-obligations" presentations to their low-wage worker and employer communities could increase both the number of workers willing to seek paid sick leave as well as the number of employers willing to provide it without resorting to retaliation. Additionally, collaboration with immigrant worker centers is another key resource as lowwage immigrants often turn to these centers for self-help and advocacy, and their outreach could include better navigation of paid sick leave laws. ${ }^{48}$

45 Mary Mallon was similarly distrustful of the New York health authorities that implored her to stop cooking for a living.

46 At least fourteen states are following a similar strategy in the occupational safety and health realm; these states have enacted local laws and enforcement mechanisms to fill the gap created by an absence of national standards addressing workplace safety specific to the COVID-19 pandemic (Berkowitz, 2020).

47 A collaborative of public health researchers at Northern Arizona University's Center for Health Equity Research working in conjunction with the Workers' Rights Clinic at the James E. Rogers College of Law currently are launching a project that will collect data to determine whether the amount of paid sick leave taken by low-wage immigrant workers would increase based on targeted outreach and education through community health workers.

48 See Worker Centers, Organizing Communities at the Edge of a Dream, available at https://digital commons.ilr.cornell.edu/cgi/viewcontent.cgi? article=1018\&context=books 
The coronavirus has devastated nursing homes across the country, killing over 160,000 residents and workers at the time of this writing (American Associations of Retired Persons Nursing Home COVID-19 Dashboard, 2021). Those numbers only reflect deaths reported (there may be many more unreported cases) and they don't account for pain and suffering related to a coronavirus infection, especially when it is acquired at an older age. Low-wage immigrant workers employed in multiple nursing home facilities did not cause the pandemic, but poor infection control, largely caused by inadequate staffing has allowed the virus to spread (Sklar \& Terry, 2020). Enforced paid sick leave laws can help curtail an infectious disease that has spiraled out-of-control, but efforts such as those highlighted above must be made to ensure that lowwage workers are able to both realize and access their rights.

\section{Conclusion}

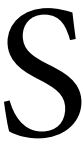
cholars who have studied Mary Mallon and similar tragic stories of poor, immigrant women frame the narrative in terms of a seemingly irreconcilable tension between "how to protect the public's health and at the same time maintain the rights and freedoms of individuals" (Walzer Leavitt, 1996, p. 205; Hoppe, 2017; Foss, 2020). In sum, these societal goals much be pursued together. Protecting low-wage immigrant workers simultaneously safeguards nursing home residents during COVID-19 or other infectious disease pandemics. Specifically, the provision and enforcement of paid sick leave rights both protects vulnerable members of the public and helps curtail COVID-19 and future outbreaks.

\section{Acknowledgements}

The authors appreciate the assistance of Arizona Law's faculty support, especially Bert Skye, for administrative assistance. The authors are grateful to Andrew Coan and Ellen Bublick for their thoughtful suggestions, to Leah Jaffe and Mary Ryan for their wisdom, and to clinic students Annabel Barraza, Yesenia Gamez Valdez and Andrea Sharp for their diligent representation of immigrant women workers in nursing homes. Special thanks to Ruqaiijah Yearby for her insightful review, to the participants at APHA 2020 Annual Meeting, as well as to Eva Kahana and Kaitlyn Barnes Langendoerfer for their helpful guidance, edits, and support.

\section{References}

A Better Balance. (2020a, February 28). Fact sheet: Nationwide paid sick days are essential for public health. https://www.abetterbalance.org/resources/factsheet-paid-sick-days-are-essential-for-public-health/

A Better Balance. (2020b, September 15). Know your rights: The Families First 
Coronavirus Response Act Paid Leave \& Paid Sick Time FAQ. https://www. abetterbalance.org/resources/know-your-rights-the-families-first-corona virus-response-act-faq/

Aleinikoff, T., Martin, D., Motomura, H., Fullerton, M., \& Stumpf, J. (2016). Immigration and citizenship: Process and policy. West Academic Publishing.

Barbaro, M., \& Dickerson, C. (2020, May 4). One Meat Plant, One Thousand Infections. The Daily Podcast. The New York Times. https://www.nytimes.com/ 2020/05/04/podcasts/the-daily/meat-processing-coronavirus.html.

Barbaro, M., \& Gebeloff, R. (2020, July 8). Counting the infected. The Daily Podcast. The New York Times. https://www.nytimes.com/2020/07/08/podcasts/ the-daily/coronavirus-data-united-states.html.

Barnett, M. L., \& Grabowski, D. C. (2020). Nursing homes are ground zero for COVID-19 pandemic. JAMA Health Forum, 1(3). https://doi.org/10.1001/ jamahealthforum.2020.0369

Berkowitz, D. (2020). Which states and cities have adopted comprehensive COVID-19 worker protections? National Employment Law Project. https:// www.nelp.org/blog/which-states-cities-have-adopted-comprehensivecovid-19-worker-protections/

Beyer, D. (2020). The impact of coronavirus on the working poor and people of color. U.S. Congress Joint Economic Committee.

Booker, B. (2020, May 18). Health care aide charged after allegedly refusing to self-isolate; Patient, 80, dies [episode]. In The Coronavirus Crisis. NPR.org. https:// www.npr.org/sections/coronavirus-live-updates/2020/05/18/858240770/ health-care-aide-charged-after-refusing-order-to-self-isolate-elderly-pa tient-di.

Bowman, C. G., Rosenbury, L. A., Tuerkheimer, D., \& Yuracko, K. A. (2018). Feminist jurisprudence: cases and materials (4th ed.). West Academic Publishing.

Boyens, C. (2020, June). State paid family and medical leave programs helped a surge of workers affected by the COVID-19 Pandemic. Urban Institute. https://www.urban.org/sites/default/files/publication/102325/state-paidfamily-and-medical-leave-programs-helped-a-surge-of-workers-affectedby-the-covid-19-pandemic_0.pdf.

Bridges, K. M. (2019). Critical race theory: A primer. Foundation Press.

Calderone, J. R., Abel, A. M., \& Rosenbaum, E. (2020). COVID-19 and undocumented immigrants. Family Doctor, A Journal of the NY State Academy 
of Family Physicians, 9(1), 37-40. http://www.nysafp.org/NYSAFP/media/ PDFs/Family\%20Doctor/Family-Doctor-Summer2020_1.pdf\#page=37.

Chen, M. K., Chevalier, J. A., \& Long, E. F. (2020, July). Nursing home staff networks and COVID-19. NBER Working Paper Series. https://www.nber.org/ papers/w27608.pdf.

Coe, N. B., \& Harold Van Houtven, C. (2020). Living arrangements of older adults and COVID19 risk: It is not just nursing homes. Journal of the American Geriatrics Society, 68(7), 1398-1399. https://doi.org/10.1111/jgs.16529.

Cohen, P., \& Hsu, T. (2020, June 11). 'Rolling Shock' as job losses mount even with reopenings. The New York Times https://www.nytimes.com/2020/05/14/ business/economy/coronavirus-unemployment-claims.html

Conlen, M., Ivory, D., Yourish, K., Lai, K.K.R., Hassan, A., Calderone, J., Smith, M., Lemonides, A., Allen, J., Blair, S., Burakoff, M., Cahalan, S., Cassel, Z., Craig, M., De Jesus, Y., Dupré, B., Facciola, T., Fortis, B., Gorenflo, G. ... Harvey, B. (2020, September 16). About $40 \%$ of U.S. Coronavirus deaths are linked to nursing homes. The New York Times. https://www.nytimes. com/interactive/2020/us/coronavirus-nursing-homes.html.

DeSilver, D. (2020, July 27). As coronavirus spreads, which U.S. workers have paid sick leave - and which don't? Pew Research Center. https://www.pewresearch.org/fact-tank/2020/03/12/as-coronavirus-spreads-which-u-sworkers-have-paid-sick-leave-and-which-dont/.

Dickerson, C. \& Shear, M. (2020, October). Before COVID-19, Trump aide sought to use disease to close borders. The New York Times. https://www.nytimes. com/2020/05/03/us/coronavirus-immigration-stephen-miller-public-health.html

Dunne, E. (2000). The embarrassing secret of immigration policy: Understanding why Congress should enact an enforcement statute for undocumented workers. Emory Law Journal, 49, 623-672.

Foo, L. J. (1994). The informal economy: The vulnerable and exploitable immigrant workforce and the need for strengthening worker protective legislation. Yale Law Journal, 103, 2179-2204.

Foss, K. A. (2020, September 6). \#Typhoid Mary - Now a hashtag - Was a maligned immigrant who got a bum rap. The Conversation. https://theconversation.com/typhoidmary-now-a-hashtag-was-a-maligned-immigrantwho-got-a-bum-rap-136571.

Garrity, E. (2017). Guacamole is extra but the norovirus comes free: Implementing paid sick days for American workers. Boston College Law Review, 58(2), 
703-742. https://lawdigitalcommons.bc.edu/bclr/vol58/iss2/7/.

Gebeloff, R, Ivory, D., Richtel, M., Smith, M., Yourish, K., Dance, S., Fortiér, J., Yu, E., \& Parker, M. (2020, September 9). The striking racial divide in how Covid-19 has hit nursing homes. The New York Times. https://www.nytimes.com/article/coronavirus-nursing-homes-racial-disparity.html.

Gerstein, T. (2020, August 27). Workers' rights protection and enforcement by state attorneys general: State AG labor right activities from 2018-2020, Economic Policy Institute and Harvard Law School Labor and Worklife Program 34. https://www.epi.org/publication/state-ag-labor-rights-activities-2018to- $2020 /$.

Gordon, J. (2005). Suburban sweatshops: The fight for immigrant rights. Harvard University Press. https://doi.org/10.4159/9780674037823

Hammonds, C., \& Kerrissey, J. (2020, May 1). A survey of essential workers' safety and security during COVID-19. U. Mass. Amherst Labor Ctr. Working Paper Series. https://www.umass.edu/lrrc/rsearch/working-papers-series/survey -essential-workers\%E2\%80\%99-safety-and-security-during-covid-19.

Heeran, G. (2011). Illegal Aid: Legal Assistance to Immigrants in the United States. Valparaiso University School of Law, ValpoScholar Law Faculty Publications, 33(2) 648, 654.

Hoppe, T. (2017). Punishing disease: HIV and the criminalization of sickness. University of California Press.

Jabour, A. (2020, May 22). Immigrant workers have borne the brunt of Covid-19 outbreaks at meatpacking plants. Washington Post. https://www.washingtonpost.com/outlook/2020/05/22/immigrant-workers-have-born-bruntcovid-19-outbreaks-meatpacking-plants/.

Jordan, M., \& Dickerson, C. (2020, April 9). Poultry worker's death highlights spread of coronavirus in meat plants. The New York Times. https://www.nytimes. com/2020/04/09/us/coronavirus-chicken-meat-processing-plants-immi grants.html.

Kumar, S., Grefenstette, J., Galloway, D., Albert, S., \& Burke, D. (2013, August). Policies to reduce influenza in the workplace: Impact assessments using an agent-based model. American Journal of Public Health 103(8),1406-1411. https://ajph.aphapublications.org/doi/abs/10.2105/AJPH.2013.301269

Lee, C., Podury, A., Kaduthodil, J., \& Graham, L. (2020, September 18). Longterm care facilities must prioritize immigrant workers' needs to contain COVID-19. Health Affairs Blog. https://www.healthaffairs.org/do/10.1377/ hblog20200914.520181/full/. 
Lin, J. (2013). A greedy institution: Domestic workers and a legacy of legislative exclusion. Fordham International Law Review, 36(3), 706-741.

Maloney, C. B., \& Schumer, C. E. (2020). Expanding access to paid sick leave: The impact of the Healthy Families Act on America's workers. Joint Economic Committee. https://www.jec.senate.gov/public/_cache/files/abf8aca76b94-4152-b720-2d8d04b81ed6/sickleavereportfinal.pdf.

National Employment Project. (2020, August 19). Labor department report: More workers speaking up, blowing the whistle on Covid safety violations-but their complaints of retaliation face delays at understaffed OSHA. https://www. nelp.org/news-releases/labor-department-report-workers-speaking-blow ing-whistle-covid-safety-violations-complaints-retaliation-face-de lays-understaffed-osha/

Oppel, R. A., Gebeloff, R., Lai, K. K. R., Wright, W., \& Smith, M. (2020, July 5). The fullest look yet at the racial inequity of coronavirus. The New York Times. https://www.nytimes.com/interactive/2020/07/05/us/coronavirus-lati nos-african-americans-cdc-data.html? referringSource $=$ article.

Quandt, S. A., LaMonto, N. J., Mora, D. C., Talton, J. W., Laurienti, P. J., \& Arcury, T. A. (2020). COVID-19 Pandemic among Latinx farmworker and non-farmworker families in North Carolina: Knowledge, risk perceptions, and preventive behaviors. International Journal of Environmental Research and Public Health, 17(16), 5786. https://doi.org/10.37473/dac/10. 1101/2020.07.14.20153429

Romm, T. (2020, April 6). Underfunded, understaffed and under siege: Unemployment offices nationwide are struggling to do their jobs. Washington Post. https://www.washingtonpost.com/business/2020/04/06/unemploymentbenefits-coronavirus/.

Sayers, J., \& Demers, J. (2020, August 28). Tucson nursing home has state's worst Covid-19 death toll. Arizona Daily Star. https://tucson.com/news/local/ tucson-nursing-home-has-states-worst-covid-19-death-toll/article_ a709daa1-ee3d-5f84-a086-aed4877bdaf9.html.

Sklar, T., \& Terry, N. P. (2020, June 9). States are making it harder to sue nursing homes over COVID-19: Why immunity from lawsuits is a problem. The Conversation. https://theconversation.com/states-are-making-it-harder-to -sue-nursing-homes-over-covid-19-why-immunity-from-lawsuits-is-aproblem- 139820

Sönmez, S., Apostolopoulos, Y., Lemke, M. K., \& Hsieh, Y. (2020). Understanding the effects of COVID-19 on the health and safety of immigrant hospitality workers in the United States. Tourism Management Perspectives, 35, https:// 
doi.org/10.1016/j.tmp.2020.100717.

The New York Times Editorial Board. (Sept. 5, 2020). How many of these 68,000 deaths could have been avoided? The New York Times. https://www.nytimes. com/2020/09/05/opinion/sunday/coronavirus-nursing-homes-deaths. html.

The State of New Jersey vs. Josefina Brito-Fernandez. (Camden City Municipal Court, 2020, May 14).

Vandinther, J. (2020, May 21). Typhoid Mary, the asymptomatic cook who infected patrons. CTV News. https://beta.ctvnews.ca/national/coronavirus/20 20/5/19/1_4944890.html.

Villarosa, L. (April 11, 2020). Why America's Black Mothers and Babies Are in a Life-or-Death Crisis. The New York Times. https://www.nytimes. com/2018/04/11/magazine/black-mothers-babies-death-maternal-mor tality.html.

Walzer Leavitt, J. (1996). Typhoid Mary: Captive to the public's health. Beacon Press.

Weston Williamson, M. (2019). The meaning of leave: Understanding workplace leave rights. New York University, Journal of Legislation \& Public Policy, 22(1), 197-268.

Wu, L. (2020, June 28). There's something about Mary. In Up First. National Public Radio. https://www.npr.org/2020/03/04/811978132/bonus-theres-some thing-about-mary.

Yearby, R., \& Mohapatra, S. (2020a). Law, structural racism, and the COVID-19 pandemic. Journal of Law and the Biosciences, 7(1). https://doi.org/10.1093/ jlb/lsaa036.

Yearby, R., \& Mohapatra, S. (2020b, May 29). Structural discrimination in COVID-19 workplace protections. Health Affairs Blog. https://www.health affairs.org/do/10.1377/hblog20200522.280105/full/

Yourish, K., Smith, M., Ivory, D., \& Lai, K. K. R. (2020, May 11). One-third of all U.S. coronavirus deaths are nursing home residents or workers. The New York Times.https://www.nytimes.com/interactive/2020/05/09/us/coronaviruscases-nursing-homes-us.html.

Zallman, L., Finnegan, K. E., Himmelstein, D. U., Touw, S., \& Woolhandler, S. (2019). Care for America's elderly and disabled people relies on immigrant labor. Health Affairs, 38(6), 919-926. https://doi.org/10.1377/hlthaff.2018. 05514.

Zimmer, C. (2020, June 30). Most people with coronavirus won't spread it. Why do a few infect many? The New York Times. https://www.nytimes. com/2020/06/30/science/how-coronavirus-spreads.html. 